\title{
PEMANFAATAN TRAVEL WRITING SEBAGAI SUMBER INFORMASI BAGI WISATAWAN NUSANTARA
}

\author{
Nikasius Jonet Sinangjoyo \\ NIDN 0518117401 \\ Email: nikasius_jonet@ampta.ac.id
}

Fian Damasdino

NIDN 0523098901

Email: fian@ampta.ac.id

Dosen Sekolah Tinggi Pariwisata AMPTA Yogyakarta

\begin{abstract}
The era of information and communication technology provides opportunities and convenience for tourists to meet their needs of self-actualization by telling their experiences through writing, so-called travel writing. Travel writing can be used as a source of information to guide some potential tourists in planning their travels. Furthermore, it can also increase the number of domestic tourists' visit to several tourist destinations spread across the nation. This research, through the descriptive qualitative approach, aims to thoroughly describe the phenomenon of the use of travel writing as the source of travel information. The informants in this research were 7 people. The data were collected through in-depth interview and questionnaire. The research results shows that magazines, newspapers and web portals have high credibility, while travel blogs have an objective and reliable. There were 5 characteristics of travel writing which expected by the reader such as simple writing, clear language, photo display, facts, and have value of benefits.
\end{abstract}

Keywords: travel writing, source of information, domestic tourists

\section{PENDAHULUAN}

Fenomena pergeseran perilaku wisatawan dari sekedar melepas rutinitas hingga beralih padakebutuhan aktualisasi diri dipengaruhi oleh pesatnya perkembangan media teknologi komunikasi dan informasi. Perkembangan media tersebut telah membawa peluang dan kemudahan bagi wisatawanuntuk memenuhi kebutuhan aktualisasi dengan memanfaatkan berbagai media untuk menceritakan pengalamannya melalui sebuah tulisan dan gambar. Peluang tersebut telah memberikan kesempatan bagi siapapun untuk menjadi travel writer atau penulis. Adapun bentuk karya tulis yang mendiskripsikan pengalaman perjalan disebut travel writing.

Travel writing merupakan bentuk karya tulis yang menceritakan pengalaman perjalanan penulis yang dibagikan kepada pembaca, beberapa diantaranya ditulis ke dalam bentuk digital media dan mediacetak, antara lain yaitu novel, buku panduan wisata,majalah, blog dan portal web. Kekuatan penulis untuk menciptakan karakternya agar masuk ke dalam imajinasipembaca, tidak sekedar membentuk kesadaran tetapi mampu mempengaruhi pembaca untuk melakukan keputusan berwisata.

Beberapa diantara karya novel yang menggambarkan daya tarik wisata 
nusantara antara lain yaitu Travel Writer Diaries oleh Teguh Sudarisman, Tahta Mahameru oleh Azzura Dayana, $5 \mathrm{~cm}$ oleh Dhonny Dhirgantoro. Dalam bentuk blog beberapa diantaranya yaitu nakedtraveler.com oleh Trinity, pergidulu.com oleh Adam dan Susan, whateverbackpacker.com oleh Adis, lucianancy.comoleh Lucia Nancy dan ranselkosong.com oleh Yunaidi Joepoet, sedangkan beberapa portal web diantaranya yaitu superadventure.co.id, phinemo.comdan nationalgeographic.grid.id.

Semakin meningkatnya karya travel writing yang mengangkat destinasi Indonesia diharapkan akan meningkatkan kunjungan wisatawan nusantara ke beberapa destinasi yang tersebar di Indonesia, sehingga travel writing dapat dimanfaatkan sebagai sumber informasi yang mampu memandu calon wisatawannusantara dalam merencanakan perjalanan. Namun berdasarkan observasi sementara justru berbanding terbalik, yaitu adanya kecenderungan animo masyarakat Indonesia untuk memilih berwisata ke luar negeri dibandingkan berwisata ke nusantara dan belum ada data akurat terkait peranan travel writing terhadap tingkat kunjungan serta sebagai sumber informasi. Penulis tertarik untuk meneliti secara mendalam tentang pemanfaatan travel writing oleh wisatawan nusantara sebagai sumber informasi.

\section{LITERATURE REVIEW Travel Writing}

Travel writing merupakan bentuk catatan pengalaman perjalanan wisata yang terdiri dari karya sastra salah satunya yaitu novel yang bersifat fiksi dan buku panduan perjalananyang bersifat non fiksi
(Nurdiyansah, 2014). Sastra perjalanan memuat tujuan yang dituangkan dalam setiap karyanya yang tercermin dalam pengalaman pengarang selama melakukan perjalanan. Melalui pengalamannya tersebut, banyak orang mengikuti jejaknya. Pembaca memberikan respon melalui sebuah tulisan, melakukan proses penerimaan terhadap ideologi dan nilai, dan memahami maksud pengarang. Melalui tahap-tahap tersebut, pengarang menghidupkan dirinya dalam jiwa pembaca. Tulisan mengenai catatan dan cerita perjalanan tidak berorientasi mimetik, namun benar-benar kisah perjalanan yang dialami dan ditulis untuk dibaca. Pembaca dituntut memahami dan menghubungkan dengan realita dan tergelitik untuk keluar dari zona nyaman dan menantang sejauh pengetahuan mereka dalam memahami halhal yang terjadi di berbagai belahan dunia (Ekasiswanto, 2017)

Novel memiliki peluang yang besar untuk memancing wisatawan. Seperti halnya dalam novel Tenggelamnya Kapal Van Der Wijck karya Hamka, yang mengangkat wujud kebudayaan Minangkabau berupa norma, aktivitas dan benda-benda hasil karya manusia. Dalam novel tersebut wujud kebudayaan tergambar jelas sehingga melalui novel diharapkan mampu sebagai pintu gerbang untuk membuat wisatawan tertarik tentang budaya Minangkabau (Pratama, Suwandi, Wardani 2017)

Sebuah buku panduan dapat dilihat sebagai alat untuk membuat wisatawan independen merasa menemukan saran dan informasi yang layak diketahui tentang tempat wisata, akomodasi, transportasi, makan (Bender, Gidlow, Fisher, 2013). Sedangkan buku panduan perjalanan merupakan media informasi pariwisata 
untuk wisatawan khususnya backpackers yang dapat dipercaya, oleh karena itu panduan perjalanan adalah cara yang tepat untuk meningkatkan reputasi akomodasi dan mengkonfirmasi keandalan (Hiransomboon, 2012)

Kebiasaan dalam menceritakan berbagai pengalaman berwisata akan menjadi sumber informasi sekaligus mampu menciptakan motivasi berwisata (Sinangjoyo dan Hartati, 2017). Adapun Proses pencarian informasi tersebut dapat menggunakan berbagai media yang dianggap dapat membantu dalam memenuhi kebutuhan informasinya, baik melalui media cetak, elektronik, maupun media interaktif yang sekarang ini berkembang pesat (Damasdino, 2007)

Wisatawan nusantara merupakan seseorang yang melakukan perjalanan di wilayah teritori Indonesia, dengan lama perjalanan kurang dari 6 bulan dan bukan untuk memperoleh penghasilan di tempat yang dikunjungi serta bukan merupakan perjalanan rutin, dengan mengunjungi kawasan wisata komersial, dan atau menginap di akomodasi komersial, dan atau jarak perjalanan lebih besar atau sama dengan 100 kilometer pergi-pulang (Barudin, Fitriyani dan Indriyati 2016).

\section{METODE PENELITIAN}

Penelitian ini menggunakan metode deskriptif kualitatif untuk menggambarkan fenomena secara mendalam terkait pemanfaatan travel writing sebagai sumber informasi bagi wisatawan baik fiksi maupun non fiksi serta cetak maupun digital. Objek penelitiannya ditentukan melalui pertim-bangan tertentusesuai tujuan yang ingin dicapai dalam penelitian.

Peneliti mengambil informan sebanyak 7 orang dengan kriteria: 1) Usia antara 20 hingga 40 tahun karena rentang usia tersebut menunjukan tingkat kedewasaaan dan kemandirian finansial. 2) Memiliki pengalaman berwisata ke destinasi nusantara dengan memanfaatkantravel writing sebagai sumber informasi. 3) Responden tergabung dalam salah satu komunitas traveler atau backpackeryang memanfaatkan travel writing sebagai sumber informasi wisata, dengan asumsi adanya kecenderungan karakter pesan yang mengisahkan tema petualangan dan memuat panduan berwisata. Instrumen pengambilan data menggunakan teknik indept interview dan kuisioner.

\section{HASIL DAN PEMBAHASAN}

Perkembangan teknologi informasi dan komunikasi diikuti dengan munculnya travel writing dalam bentuk digital serta berkembangnya komunitas traveling yang mampu menciptakan kemudahan dan keragaman sumber informasi. Dengan demikian peran media informasipun akan semakin beragam pula, baik sebagai sumber informasi utama, sebagai media pembandingmaupun sebagai media pendukung. Disisi lain dengan adanya fenomena tersebut justru pembaca akan semakin selektif dalam memilih dan memanfaatkan beberapa jenis travel writing.

Berdasarkan data yang diperoleh menunjukan bahwa mayoritas menganggap sumber informasi melalui majalah, surat kabar dan portal web terkesan memiliki kredibilitas tinggi dibandingkan dengan tulisan yang bersumber dari sebuah blog. Adanya persaingan dalam hal publikasi serta keharusan penulis untuk memenuhi permintaan editor atau perusahaan tertentu, justru akan meningkatkan kredibilitasnya 
dimata pembaca. Di sisi lain bahwa atas dasar pemenuhan permintaan tersebut, maka tulisan yang disampaikan justru akan menjadi kurang objektif karena penulis selalu dituntut untuk memenuhi permintaan yang cenderung bermuatan bisnis atau komersil sehingga terkesan selalu menyampaikan materi yang bersifat berlebihan.

Travel blog dianggap kurang memiliki kredibilitas apabila dibandingkan dengan jenis travel writing lainnya karena travel bloghanya menyampaikan pengalaman perjalanan sesuai kemauan penulis tanpa melalui penyuntingan editor dan dianggap kurang mempertimbangkan kebutuhan pembaca. Namun demikian blog memiliki segmen pembaca yang kompetitif karena menyediakan pilihan komunikasi secara langsung yang memudahkan pembaca untuk memberikan umpan balik. Adanya ketersediaan komunikasi secara langsung mampu menciptakan kesan lebih objektif dan mudah dipercaya.

Kategori non fiksi untuk jenis buku panduan berwisata dan portal web cenderung dimanfaatkan sebagai sumber informasi utama, mengingat media ini menawarkan kepada pembaca untuk berwisata secara efektif dan efisien khususnya terkait persiapan waktu dan biaya. Selain itu yang menjadi pertimbangan utamanya yaitu pemenuhan kebutuhan wisatawan terhadap kepastian jarak tempuh, peta lokasi, jalur serta pemilihan moda transportasi.

Travel writing dalam bentuk novel dianggap memiliki kredibilitas tinggi, meskipun sebagai karya fiksi namun memiliki segmen pembaca khusus. Beberapa karya novel yang mengangkat pesona nusantara telah diadaptasi menjadi sebuah film diantaranya seperti Nekad Traveller, $5 \mathrm{~cm}$ dan Laskar Pelangi. Pembaca menganggap bahwa karya novel memiliki makna psikologis yangdapat membangkitkan emosi pembaca melalui sentuhan humor, nuansa romantis, kisah inspratif dan selalu mengajak pembaca untuk berimajinasi. Novel dianggap kurang dinamis terutama dalam hal penyampaian alokasi waktu dan biaya perjalanan karena isi tulisan tidak mudah diperbaharui. Berbeda halnya dengan blog, portal web atau surat kabar dan majalah yang akan tergantikan oleh edisi berikutnya. Dengan demikian novel akan dianggap mudah ketinggalan zaman, terlebih apabila destinasinya memiliki tingkat perkembangan tinggi yang selalu memunculkan atraksi-atraksi baru. Pembaca atau penggemar novel sengaja meman-faatkan novel sebagai faktor pendorong utama dalam berwisata karena tujuan mereka berwisata yaitu untuk membuktikan tulisan yang telah mereka bacadan memanfaatkan karya non fiksi sebagai media pembanding atau sebagai media pendukung. Hal tersebut dirasa karena novel dianggap kurang spesifik dan hanya menawarkan pengalaman tunggal dari penulis sedangkan kategori non fiksi dianggap memiliki beberapa pilihan penawaran informasi.

Penelitian ini menggunakan 5 aspek penilaian tentang karakterisitik travel writing yang diharapkan oleh pembaca antara lain yaitu : 1) Tulisan sederhana, 2) Bahasa yang jelas, 3) Tampilan foto, 4) Unsur fakta 5) Nilai manfaat. Kelima aspek tersebut mengadopsi dari sebagian karakter travel writing yang dikemukakan oleh Mishra, (2014). Adapun hasil survei tersebut seperti dalam gambar 1: 


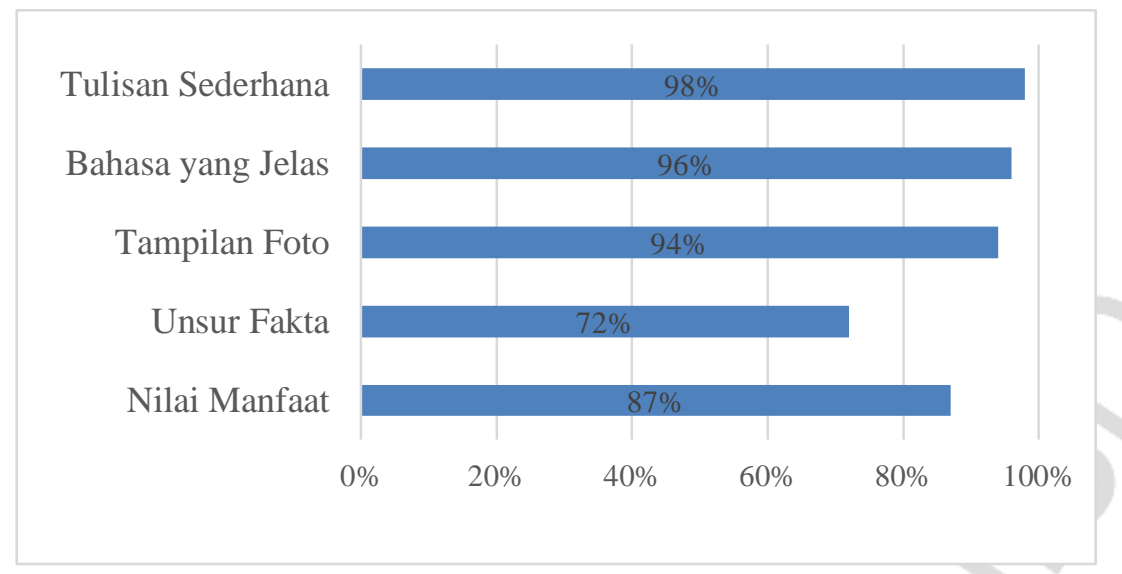

Gambar 1. Karakteristik Travel Writing

Berdasarkan gambar 1 menunjukkan bahwa sebesar 98\% memiliki preferensi terhadap tulisan sederhana yang disampaikan secara mendetail dengan menggunakan kata-kata yang mudah dipahami dan tidak mengandung pernyataan yang berlebihan. Adanya beberapa penilaian terhadap gaya penulisan seperti tema yang terlalu romantis, terlalu imajinatif, atau terlalu akademis akan menimbulkan kesan yang kurang menarik dimata pembaca. Dengan demikian perlu adanya pemahaman bagi penulis agar menempatkan cara pandangnya sesuai kebutuhan segmen demografis dan psikografis pembaca. Kemampuan target pembaca dalam memahami makna tulisan dipengaruhi oleh tingkat pemahaman, kemampuan berimajinasi, selera dan motivasi yang berbeda-beda mengingat terdapat pembaca yang ingin menikmati tulisan secara umum atau hanya sebagian cerita tertentu yang dianggapnya paling menarik.

Terkait penggunaan bahasa yang jelas, sebesar 96\% menanggapi pentingnya mengikuti kaidah penulisan yang baik dan benar. Bahasa yang jelasakan membuat pembaca tidak merasa lelah dan tidak membuang-buang waktu sekedar untuk memahami makna tulisan. Mayoritas penulis merupakan wisatawan independent yang berkunjung ke suatu destinasi yang tidak biasa dikunjungi oleh wisatawan pada umumnya. Dengan demikian perlu adanya deskripsi dan bahasa secara jelas agar dapat memberikan informasi berupa saran sebagai panduan berwisata, salah satunya yaitu saran dalam memaksimalkan waktu dan penghematan biaya perjalanan. Dalam upaya memperkuat citra destinasi nusantara, maka dalam karya fiksi diperlukan penambahan nilai-nilai kelokalan seperti dialog yang melibatkan komunitas lokal, penggunaan bahasa lokal, kisah petualangan alam dan budayalokalserta tema humor khas nusantara agar pembaca merasa tertarik dan mudah untuk mendiskripsikannya. Rasa humor yang menghibur harus tetap relevan dengan tema tulisan serta tidak menimbulkan dampak negatif terhadap kearifan lokal. Penggunaan bahasa yang jelas juga akan menghilangkan kesan buruk terhadap penulis yang seolah-olah sengaja menyembunyikan kejadian-kejadian negatif serta pengunaan ungkapan-ungkapan halus untuk menggantikan kesan negatif yang kemungkinan akan menimbulkan kesan yang tidak menyenangkan.

Sebesar 94\% menganggap bahwa tampilan foto sangat penting karena dapat 
merangsang indera pembaca. Pembaca dapat merasakan seolah-olah sedang berada di destinasi dan dapat merasakan seperti yang dialami oleh penulis. Melalui foto pembaca dapat menemukan potensi pariwisata nusantara yang tidak pernah terpikirkan oleh wisatawan pada umumnya, dari atraksi yang biasa menjadi atraksi yang luar biasa. Tampilan foto tentang keindahan, keunikan, dan keanekaragaman atraksi nusantara dipahami sebagai upaya untuk menghidup-kan tulisan dengan mengkombinasikan nilai-nilai kelokalan melalui bentuk visualisasi. Mayoritas menyebutkan bahwa antara narasi dan foto tidak dapat dipisahkan, sebaik apapun narasi yang dibuat tanpa adanya foto maka tulisan tersebut tidak akan menarik. Upaya tersebut sekaligus untuk mengatasi keterbatasan karakteristik produk pariwisata yang cenderung bersifat intangible. Tampilan foto tidak sekedar menampilkan gambar-gambar yang indahdengan tujuan menarik pembaca untuk berwisata, tetapi melalui foto-foto yang bertanggung jawab maka pembaca akan mendapatkan kebenaran visual yang bersifat informatif, persuasif dan inspiratif dengan menampilkan sisi kejujuran dari sebuah tulisan.

Tanggapan terhadap unsur fakta sebesar $72 \%$, meskipun novel sebagai karya fiksi namun nilai kejujuran dan kebenaran objektif tetap menjadi preferensi pembaca. Penggemar karya fiksi menyadari bahwa novel sebagai sastra perjalanan merupakan bentuk penulisan yang bersifat subjektif karena bukan sebagai karya ilmiah. Dengan demikian pembaca karya fiksi tidak menuntut kebenaran secara ilmiah begitu pula dengan karya non fiksi. Dalam karya novel selalu menampilkan penokohan seseorang yang sebenarnya merupakan pengalaman penulis, sehingga karya tulisan tersebut benar-benar menjadi gambaran dari pengalaman penulis. Penulis seolah-olah menjadi tokoh orang lain yang akan menghasilkan tulisan objektif berupa fakta yang dialami pembaca sehingga memberikan kesan nyata di mata pembaca. Maka tidak jarang novel dimanfaatkan sebagai sumber informasi yang lebih dipercaya dibandingkan dengan karya non fiksi.

Sebesar $87 \%$ menanggapi bahwa travel writing memiliki manfaat bagi pembacanya. Pertimbangan pembaca dalam pemilihan travel writingselain mengutamakan tema dan penokohan karakter juga terdapat pertimbangan lainyaitu latar pengambilan lokasi, waktu, dan budaya setempat. Sifat informatif tidak sekedar sebagai pedoman untuk memilih penginapan, moda transportasi, alokasi waktu, dan biaya perjalanan, namun bermanfaat sebagai pedoman terkait segala sesuatu yang harus dilakukan dan yang tidak boleh dilakukan saat berada di destinasi. Travel writing diharapkan dapat menginspirasi pembaca agar menjadi wisatawan yang tidak hanya melepas rutinitas tetapi turut bertanggung jawab terhadap keberlanjutan destinasi. Dengan demikian akan bermanfaat dalam menjaga keseimbangan antar berbagai kepentingan yaitu antara kualitas pengalaman berwisata, tujuan pemangku kepentingan, keberlanjutan lingkungan, budaya serta kualitas hidup komunitas lokal.Tema imajinatif tidak sebatas fiksi namun memiliki kekuatan untukmerubah imajinasi menjadi kenyataan dan memberikan pendidikan bagi pembaca agar memiliki kekaguman terhadap keindahan, keunikan dan keanekaragaman atraksi yang tersebar 
di seluruh nusantara melalui penokohan dalam cerita.

\section{KESIMPULAN DAN REKOMENDASI}

Majalah, surat kabar dan portal web memiliki kredibilitas tinggi dibandingkan dengan tulisan yang bersumber dari sebuah blog, namun dianggap kurang objektif karena cenderung memiliki muatan bisnis atau komersil mengingat adanya permintaan dari editor atau perusahaan tertentu. Berbeda halnya dengan travel blog yang menyediakan pilihan komunikasi langsung untuk memudahkan pembaca dalam memberikan umpan balik sehingga lebih terkesan objektif dan mudah dipercaya. Karya novel memiliki karakter kurang dinamis, kurang spesifik dan hanya menawarkan pengalaman tunggal dari travel writer. Terdapat 5 aspek penilaian tentang karakterisitik travel writing yang diharapkan oleh pembaca antara lain yaitu tulisan sederhana, bahasa yang jelas, tampilan foto, unsur fakta, dan nilai manfaat.

Implikasi managerial dalam
penelitian ini antara lain yaitu perlunya travel writer memahami kebutuhan pembaca berdasarkan segmen demografis dan psikografis. Dalam upaya memperkuat citra destinasi nusantara, maka dalam karya fiksi diperlukan adanya penambahannilai-nilai kelokalan seperti dialog yang melibatkan komunitas lokal, penggunaan bahasa lokal, kisah petualangan alam dan budaya lokal serta tema humor khas nusantara agar pembaca merasa tertarik dan mudah untuk mendiskripsikannya. Tampilan foto tidak sekedar menampilkan gambar-gambar yang indah tetapi foto yang bertanggung jawab dengan menampilkan sisi kejujuran dari sebuah tulisan serta mengkombinasikan nilai-nilai kelokalan melalui bentuk visualisasi. Sifat informatif tidak sekedar sebagai panduan perjalanan, namun harus menginspirasi pembaca agar menjadi wisatawan yang baikserta memiliki kekaguman terhadap keindahan, keunikan dan keanekaragaman atraksi yang tersebar di seluruh nusantara.

Sebagai saran untuk kajian penelitian berikutnya yaitu 1) Peneliti sebaiknya memisahkan jenis travel writingke dalam kategori fiksi dan non fiksi, karena pembaca atau calon wisatawan memiliki pola yang jauh berbeda dalam pemanfaatan kategori travel writing, baik sebagai sumber informasi utama, sebagai media pembanding ataupun sebagai media pendukung. 2) Peneliti dapat membandingkan pemanfaatan media bermuatan bisnis dengan media yang tidak memiliki muatan bisnis atau membandingkan antara pemanfaatan travel blog dengan pemanfaatan majalah, surat kabar, buku panduan perjalanan dan portal website, mengingat tingkat kredibilitas dan objektifitas dari kedua kategori tersebut memiliki tingkat perbedaan. 3) Penelitian lebih lanjut dapat membandingkan pemanfaatan travel writing antara wisatawan nusantara dengan wisatawan mancanegara dan implikasinya bagi pengembangan travel writing Indonesia.

\section{DAFTAR PUSTAKA}

Barudin, Ida Ambar Fitriyani, Diana Indriati. 2016. Statistik Profil Wisatawan Nusantara Tahun 2016. Jakarta: Kementrian Pariwisata.

Bender, J., Gidlow, B.,dan Fisher, D. 2013 "National Stereotypes in Tourist Guidebooks: An analysis of autoand hetero- stereotypes in English, American, German, Swiss, Spanish 
and French guidebooks about Switzerland.," Annals of Tourism Research, 40, hal. 331-351.

Deri Rachmad Pratama, Sarwiji Suwandi,

Nugraheni Eko Wardani. 2017

"Keunikan Budaya Minangkabau Dalam Novel Tenggelamnya Kapal Van Der Wijck Karya Hamkadan Strategi Pemasarannya Dalam Konteks Masyarakat Ekonomi ASEAN," Proceedings of Education and Language International Conference, 1(1), hal. 221-235.

Fian Damasdino. 2007. "Dinamika Akses Informasi Wisatawan Antar Generasi Pada Obyek Wisata Minat Khusus di Kabupaten Bantul," Media Wisata, 15(1), hal. 587-594.

Hiransomboon, K. 2012. "Marketing Mix Affecting Accommodation Service Buying Decisions of Backpacker Tourist Traveling at Inner Rattanakosin Island in Bangkok, Thailand," Procedia - Social and Behavioral Sciences. Elsevier B.V., 3(12), hal. 276-283.

Mishra, S. 2014 "Travelogues : An Innovative and Creative Genre of Literature," International Journal of English and Literature, 4(4), hal. 45-50.

Nikasius Jonet Sinangjoyo, dan Hartati S.

E. 2017 "Kajian Pasar Wisata Pulau

Kumala dan Implikasinya terhadap Pemasaran Pariwisata Yang Bertanggung Jawab.," Khasanah Ilmu, 8(2), hal. 14-19.

Nurdiansyah. 2014. Peluang dan Tantangan Pariwisata Indonesia. Bandung: Alfabeta.

Rudi Ekasiswanto. 2017 "Penggambaran
Dunia dalam The Naked Traveler 1 Year Round-The-World Trip Karya Trinity: Analisia Sastra Perjalanan Carl Thompson," Semiotika, 18(1), hal. 42-58. 